Jpn. J. Oral Biol., $42:$ 193-205, 2000.

\title{
ORIGINAL
}

\section{In Vitro Effects of Collagenase on Biomechanical Properties and Morphological Features of the Rat Molar Periodontal Ligament}

\author{
Jiro Kawada and Koichiro Komatsu* \\ Department of Periodontics \& Endodontics and \\ *Department of Pharmacology, School of Dental Medicine, Tsurumi University \\ 2-1-3 Tsurumi, Tsurumi-ku, Yokohama 230-8501, Japan \\ (Received on November 9, 1999 ; Accepted on February 15, 2000)
}

Key words: periodontal ligament/biomechanics/polarized light microscopy / collagenase / collagen

\begin{abstract}
Biomechanical properties and morphological features of the rat molar periodontal ligament were examined after treatment with various concentrations of bacterial collagenase. Treatment with collagenase caused dose-dependent decreases in the maximum shear stress, maximum shear strain, tangent modulus, and failure strain energy density of the periodontal ligament. Light microscopic analysis after mechanical testing revealed that in controls, the periodontal ligament ruptured in the middle region or near the bone surface, while in the collagenase-treated specimens, it ruptured at the region adjacent to the cementum surface. Scanning electron microscopy revealed considerable degradation of the periodontal collagen fibres and fibrils by the enzyme. Treatment with collagenase markedly reduced the phase retardation values of collagens and the areas occupied by birefringent collagen fibres within the ligament. We suggest that collagenase treatment causes a decrease in the amount and density of collagen fibres and a disorganization of the fibres that reduces the strength, extensibility, stiffness, and toughness of the ligament. Our findings indicate that the periodontal collagens are load-bearing, key structural components providing structural and functional integrity to the ligament.
\end{abstract}

抄録：ラット€歯横断標本をコラゲナーゼ溶液 $(0,8,16$ および 24 units $/ \mathrm{m} l)$ によって処理した後, 歯根膜の 機械的性質の測定および形態学的観察を行った。コラゲナーゼ処理によって, 濃度依存性に歯根膜の最大剪断応 力, 最大剪断歪, 剪断弾性率および破壊エネルギーが減少した。機械的性質測定後に作製した組織切片を光学顕 微鏡にて観察したところ, 対照標本において歯根膜は中央部または歯槽骨側で破断していたが, コラゲナーゼ処 理標本においては主にセメント質表面付近で破断していた。また，走査電子顕微鏡観察により，歯根膜コラーゲ ン線維や原線維の大部分が, 醅素によって分解, 除去されたことが判明した。偏光顕微鏡像の計測においては, コラゲナーゼ処理後, リターデーション值および複届折性を示すコラーゲン線維の占める面積が著明に低下した。 これらの結果から, コラゲナーゼ処理によって, コラーゲン線維の量と密度が減少し，また線維の配列が乱れた ために, 歯根膜の強度, 伸展性, 硬さおよび粘り強さが低下したものと推察された。今回の実験によって, コラー ゲン線維は荷重を支持するための重要な成分であり, 歯根膜の構造と機能を維持するために主要な役割を担って いるという考えを実証することができた。

\section{Introduction}

The most apparent role of the periodontal ligament is to support the tooth during function and to resist external forces applied to the tooth ${ }^{11}$. This role seems closely related to the biomechanical properties of the ligament ${ }^{2,3)}$. The periodontal ligament consists mainly of collagenous fibres (with a few oxytalan fibres) and an interfibrillar matrix ${ }^{1,4}$. 
The support function of periodontal collagen fibres has been examined in the incisors and molars of lathyrogen-treated rats $^{5-8)}$ and rabbits ${ }^{9}$. In addition, changes in the shape of the load-deformation curve of the rat incisor periodontal ligament during axial loading are reportedly closely associated with changes in the arrangement of collagen fibres ${ }^{10}$.

A number of techniques have been developed to remove various components from connective tissues so that the biomechanical properties may be measured before and after treatment, with any changes being ascribed to the missing components ${ }^{11}$. In the periodontal ligament of rat molars, it has been shown that removal of interfibrillar components using $\alpha^{-}$ amylase $^{12)}$, EDTA, a chelating agent, and low-pH acid solutions ${ }^{13)}$ caused marked reductions in the strength, stiffness, and toughness of the ligament.

However, the precise interrelations between the periodontal collagen fibres and the interfibrillar matrix are not fully understood, and the in vitro effects of collagenase on the biomechanical properties of the periodontal ligament have not been previously investigated.

We examined the in vitro effects of collagen removal on the biomechanical properties of the periodontal ligament of the rat molar, and attempted to elucidate the interrelation between collagen fibres and the interfibrillar matrix for maintaining its biomechanical properties.

\section{Materials and Methods}

\section{Preparation of rat molar periodontal liga- ment}

Twenty-four male Wistar rats, 5 weeks of age, were fed a powdered diet and given water ad libitum for 7-9 days. The animals were killed by ether overdose at 6 weeks of age. The right and left mandibles were immediately dissected free and adhering soft tissues were removed. From each mandible, a transverse section of the mandibular first molar, with its surrounding periodontal ligament and alveolar bone, was cut through an axis perpendicular to the long axis of the mesial root at the middle part of the root $^{14}$, using a low-speed bone saw (Isomet, Buehler, IL, USA). The average thickness of sections was $455 \pm 18$ (SD) $\mu \mathrm{m}$. The sections were kept in phosphate-buffered saline (PBS, $\mathrm{pH} 7.2,4^{\circ} \mathrm{C}$ ) until treatment with collagenase. The mean time from killing the animals until the treatment was $171 \pm 32(\mathrm{SD}) \mathrm{min}$.

\section{Radiographic analysis}

Radiographs of the transverse sections were taken with a soft-X-ray apparatus (Type EMB, Softex, Japan). The radiographic images were processed in an image analyzer (Luzex $3 \mathrm{U}$, Nikon, Japan). We measured the perimeters of the mesial root and socket wall, and the sectional area of the periodontal ligament. The area of the periodontal ligament facing the root cementum was calculated as the thickness of the section $\times$ perimeter of the cementum. The average width of the periodontal ligament was also calculated as the sectional area of the periodontal ligament/ (perimeter of cementum + perimeter of socket wall) / $2^{14)}$.

\section{In vitro treatment with collagenase}

Transverse sections of the periodontal ligament obtained from the right mandibles were divided into four groups of 6 specimens each. Each group was treated with $0,8,16$, or 24 units of highly purified collagenase (from Clostridium histolyticum, type VII : activity of collagen digestion : 1,600 units/mg ; Sigma, USA) per milliliter of PBS. Each section was placed in $1 \mathrm{~m} l$ of a test solution and shaken (150 times/min) using an incubator (Bio-Shaker $40 \mathrm{BR}-\mathrm{LF}$, Taitec Co., Japan) at $37^{\circ} \mathrm{C}$ for $4 \mathrm{~h}$. The concentrations of collagenase in test solutions were determined according to our preliminary experiments, and the incubation time was based on our previous studies ${ }^{12,13)}$. After incubation, the specimens were washed 3 times with cold PBS. The specimens were stored in PBS at approximately $4^{\circ} \mathrm{C}$ until mechanical testing. The mean time from the end of incubation until mechanical testing was $35 \pm 12$ (SD) min.

\section{Mechanical testing}

The assembly and characteristics of the testing machine and the method of loading have been previously described ${ }^{14,15)}$. In short, the bony part of the 
transverse section was clamped between two plates in a sample chamber filled with PBS. The mesial root of the first molar was pushed out of the alveolar bone by a metal rod attached to a load cell at $5 \mathrm{~mm} / \mathrm{min}$ in an extrusive direction until failure of the periodontal ligament occurred. The load-deformation curve was then recorded. All experiments were performed at room temperature of $24-26^{\circ} \mathrm{C}$.

Shear stress values $(\mathrm{MPa})$ were calculated by dividing the load values $(\mathrm{mN})$ by the area of the ligament facing the root cementum $\left(\mathrm{mm}^{2}\right)$. Shear strain values were approximated as deformations $(\mathrm{mm})$ per average width $(\mathrm{mm})$ of the ligament ${ }^{16-18}$. The load-deformation curve was then standardized into a stress-strain curve. From this curve, we estimated the maximum shear stress, maximum shear strain, tangent modulus, and failure strain energy density ${ }^{19,20)}$.

\section{Morphological examinations}

After mechanical testing, the specimens treated with 0 (control) or $24 \mathrm{units} / \mathrm{m} l$ of collagenase were fixed in $10 \%$ neutral buffered formalin and processed for morphological examination. The specimens obtained from the left mandibles were treated in the same manner as those from the right mandible, and they were used for morphological examination, without mechanical testing.

1) Light microscopy: Three specimens of the separated bone and tooth parts after mechanical testing were re-fixed and demineralized in Bouin fixative solution for 2 weeks. Frozen sections were cut transversely on a microtome (Model 1320, Leica Instruments, Germany) at a setting of $20 \mu \mathrm{m}$, stained with haematoxylin and eosin, and observed with a light microscope (Laborlux, Leica Microscopie, Germany). Light microscopic images were photographed on 35-mm colour positive film (Sensia II, Fuji Film, Tokyo, Japan). The films were scanned and digitized at $7,328 \times 4,896$ pixels (one pixel corresponds to $3.3 \times$ $\left.3.3 \mu \mathrm{m}^{2}\right)$ at an 8 -bit gray level using a film scanner (Canoscan $2700 \mathrm{~F}$, Canon, Tokyo, Japan) and a personal computer (Power Macintosh 8600/250, Apple Japan, Tokyo, Japan). The sectional areas of the periodontal ligament adhering to the root and bone surfaces were estimated using a computer program (NIH Image 1.61, Bethesda, MD, USA). The equipment was calibrated using an objective scale (Carl Zeiss, Germany).

2 ) Scanning electron microscopy: The remaining three specimens of the separated root and socket bone after mechanical testing were dehydrated in a graded ethanol series, critical-point dried, mounted on stubs, and coated with gold. Sheared surfaces of the periodontal ligament were observed with a scanning electron microscope (JSM-T 300, JEOL, Japan) operated at $15 \mathrm{kV}$.

3 ) Polarized light microscopy: Specimens from the left mandibles without mechanical testing were demineralized in 7\% EDTA solution ( $\mathrm{pH} 7.2$ ), and embedded in glycol methacrylate. Bucco-lingual sections parallel to the long axis of the mesial root were cut serially on a microtome (Supercut 2050, Leica Instruments, Germany) set at $7 \mu \mathrm{m}$, mounted in Diatex (refractive index 1.50; AB Wilch. Becker, Sweden) without staining and observed with a polarized light microscope (Laborlux 12 pol S, Leica Microscopie, Germany). Some sections were stained with toluidine blue for histological evaluations.

(1) Measurement of phase retardation: The strength of birefringence (B) can be expressed as $\mathrm{B}=\Gamma / \mathrm{t}$

where $\Gamma$ is the phase retardation and $t$ is the thickness of the birefringent material ${ }^{21}$. Assuming that the thickness of sections is constant, we estimated the strength of birefringence by measuring the phase retardation (degree) of collagen on unstained sections with the polarized light microscope at a light source voltage of $10 \mathrm{~V}$. We also used a strainfree planachromat $40 \times$ objective lens and Sénarmont compensator under monochromatic light $(\lambda=546 \mathrm{~nm})^{22,23)}$. One section was selected from each animal. The cementum surface was used as a reference line. Measurements were made from the cementum surface towards the alveolar bone across the periodontal ligament in 6 successive rectangular areas $(30 \mu \mathrm{m}$ in depth, $90 \mu \mathrm{m}$ in width), as shown in Fig. 1. In 11 specimens, no alveolar bone was observed in areas $1-4(0-120 \mu \mathrm{m})$, although 1 control specimen did contain bone in area 4 . Eight specimens had alveolar 

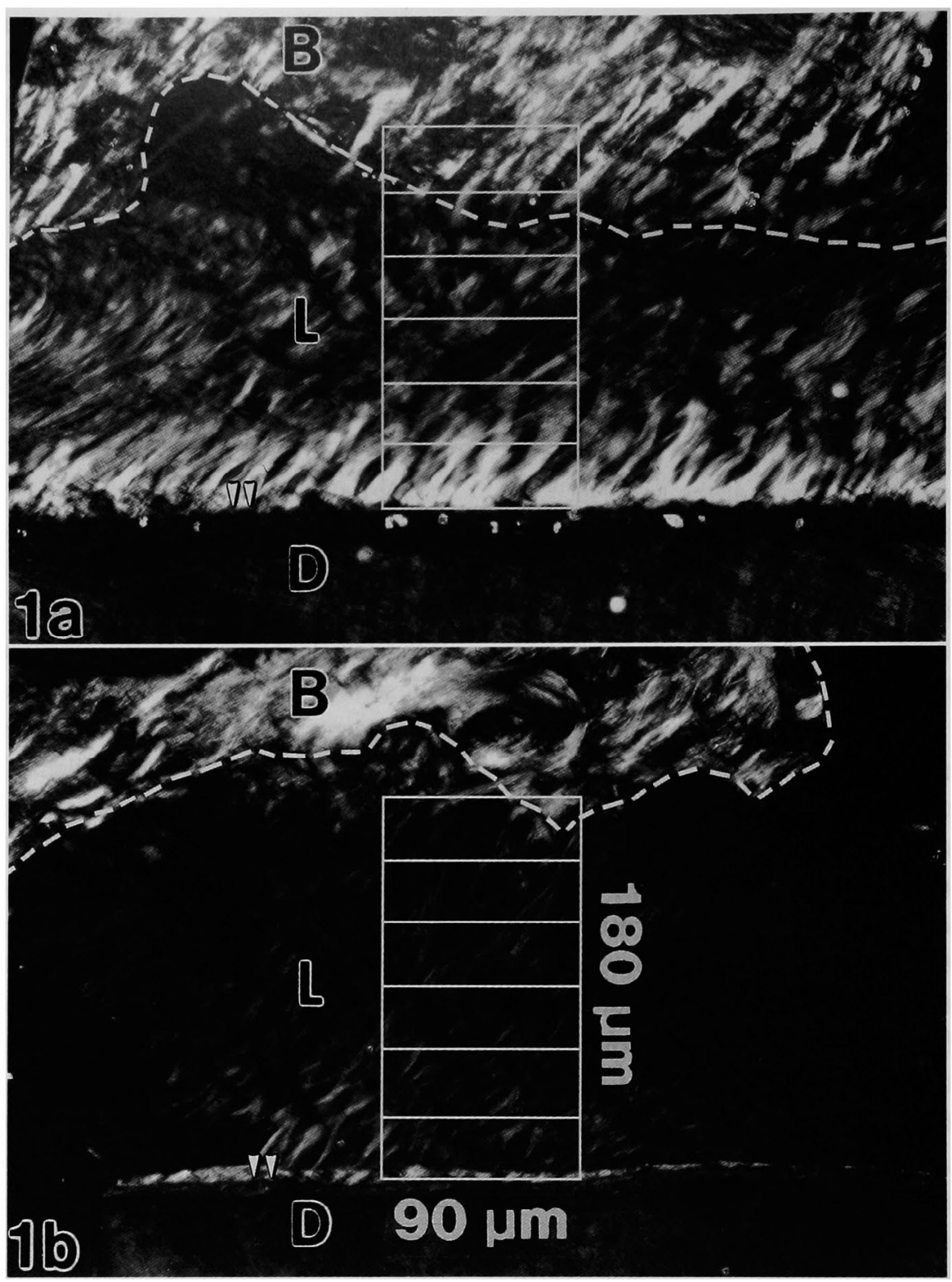

Fig. 1 Polarized light micrographs of the periodontal ligament on the buccal side of the mesial roots of the mandibular first molar. The phase retardation of collagen and the area occupied by birefringent collagen fibres with maximum brightness were estimated in 6 successive rectangular areas (30 $\mu \mathrm{m}$ in depth, $90 \mu \mathrm{m}$ in width) from the cementum surface towards the alveolar bone across the periodontal ligament on unstained sections. Sections were obtained from specimens treated with PBS (1 a) or $24 \mathrm{units} / \mathrm{m} l$ of collagenase solution $(1 \mathrm{~b})$. Dotted lines indicate the border between the bone and periodontal space. B, bone ; D, dentine ; L, periodontal ligament ; arrowheads, cementum.

bone in area $5(120-150 \mu \mathrm{m})$, and all 12 specimens had at least some alveolar bone in area 6 (150-180 $\mu \mathrm{m})$.

(2) Estimated area occupied by birefringent col- 
Table 1 Data obtained from radiographs of the mesial root of the rat mandibular first molar

\begin{tabular}{ll}
\hline Perimeter of cementum $(\mathrm{mm})$ & $3.16 \pm 0.09$ \\
Perimeter of socket wall (mm) & $4.70 \pm 0.08$ \\
Sectional area of PDL $\left(\mathrm{mm}^{2}\right)$ & $0.48 \pm 0.01$ \\
Area of PDL facing cementum $\left(\mathrm{mm}^{2}\right)$ & $1.43 \pm 0.06$ \\
Average width of PDL (mm) & $0.12 \pm 0.00$ \\
\hline
\end{tabular}

Mean \pm 1 SD of 24 animals is shown. PDL, periodontal ligament. Area of PDL facing cementum $=$ thickness of a transverse section of the molar $\times$ perimeter of cementum. Average width of PDL = sectional area of $\mathrm{PDL} /$ (perimeter of cementum + perimeter of socket wall) $/ 2$.

lagen fibres with maximum brightness : In each unstained section, the rotation angle of the polarized light microscope was set at the maximum brightness of the birefringent collagen fibres ${ }^{10)}$. A polarized light microscopic image was then taken using a strainfree planachromat $25 \times$ objective lens on $35-\mathrm{mm}$ colour positive film (Sensia II, Fuji Film, Tokyo, Japan) at an exposure time of $22 \mathrm{sec}$ and a light source voltage of $11.5 \mathrm{~V}$. The films were scanned and the area (\%) occupied by birefringent collagen fibres was estimated (NIH Image 1.61, Bethesda, MD, USA) in each of 6 rectangular areas (Fig. 1). One section was observed from each of 6 animals.

\section{Statistical analysis}

One-way analysis of variance (ANOVA) was used to examine the difference of the mean values of mechanical parameters among the groups treated with various concentrations of collagenase. The difference of the mean values between two groups was examined by Scheffé's method ${ }^{24)}$ or by Student's $t$-test, where appropriate.

\section{Results}

The mean body weight of the rats was $184 \pm 6$ (SD) $\mathrm{g}$ and the weights of the left and right mandibles were $305 \pm 10 \mathrm{mg}$ and $305 \pm 8 \mathrm{mg}$, respectively. Table 1 shows the data obtained from radiographs of the mesial root of the mandibular first molar. The area of

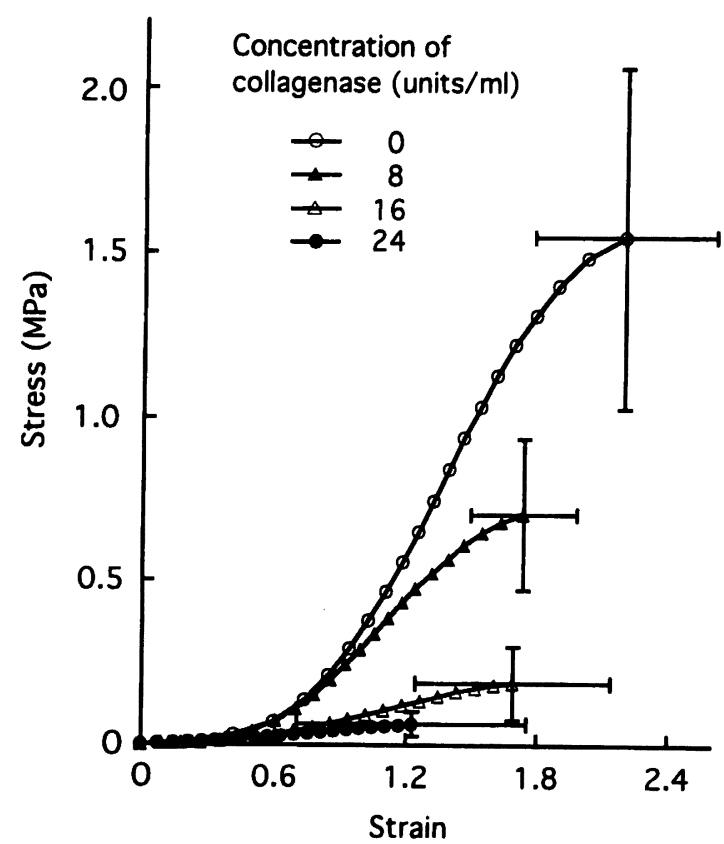

Fig. 2 Stress-strain curves of the periodontal ligament obtained from transverse sections of the mesial root of the mandibular first molar incubated in 0,8 , 16 , or 24 units of collagenase $/ \mathrm{m} l$ of $\mathrm{PBS}$ at $37^{\circ} \mathrm{C}$ for $4 \mathrm{~h}$. The end-point of each curve represents mean values for the maximum shear stress and shear strain. Vertical and horizontal bars represent \pm 1 SD of 6 animals for the maximum shear stress (vertical) and the maximum shear strain (horizontal).

the periodontal ligament facing the cementum ranged from 1.31 to $1.54 \mathrm{~mm}^{2}$. The average width of the ligament was 0.12 to $0.13 \mathrm{~mm}$.

\section{Stress-strain curves for the periodontal liga- ment}

Figure 2 shows the stress-strain curves of the periodontal ligament obtained from transverse sections of the mesial root of the mandibular first molar incubated in $0,8,16$, or 24 units of collagenase $/ \mathrm{m} l$ of PBS at $37^{\circ} \mathrm{C}$ for $4 \mathrm{~h}$. The graph shows only the rising parts of the stress-strain curves. Each curve exhibits an initial non-linear region, followed by a linear region and subsequent yielding prior to the maximum point. Increasing the concentrations of collagenase gradually decreased the slopes of the linear part of the curves, the maximum shear stresses, and maximum 

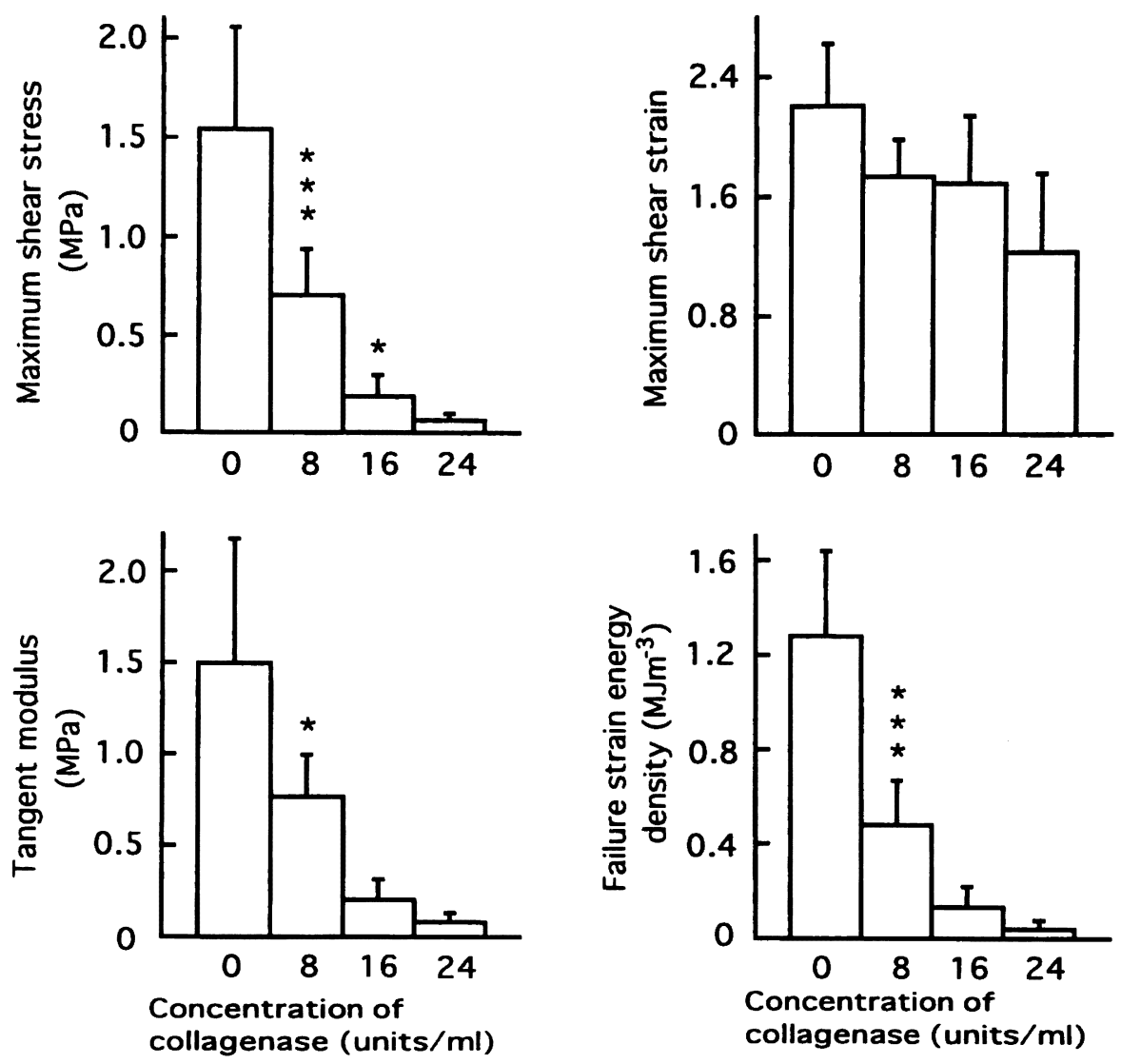

Fig. 3 Biomechanical measures for the periodontal ligament estimated from stress-strain curves obtained after treatment with various concentrations of collagenase solution. Each column and vertical bar represent mean $+1 \mathrm{SD}$ of 6 animals. Significant differences from the value at one step lower concentration of collagenase solution (Scheffé's method) : ${ }^{*} \mathrm{p}<0.05$, ${ }^{* * *} \mathrm{p}<0.001$.

shear strains.

\section{Biomechanical measures for the periodontal ligament}

Figure 3 shows the biomechanical measures estimated from the stress-strain curves represented in Fig. 1. As the concentration of collagenase increased, the maximum shear stresses, tangent moduli, and failure strain energy densities gradually decreased (ANOVA, $\mathrm{p}<0.0001$ ). The maximum shear stresses decreased from 1.54 to $0.06 \mathrm{MPa}$ (96\%) over the entire range, the tangent moduli decreased from 1.50 to $0.08 \mathrm{MPa}(95 \%)$, and the failure strain energy densities decreased from 1.28 to $0.04 \mathrm{MJm}^{-3}$ (97\%). The maximum shear strains also decreased signifi- cantly (ANOVA, $\mathrm{p}<0.01$ ) but more gradually, from 2.19 to $1.23(44 \%)$ over the entire range.

\section{Morphological observations}

1) Sites of rupture in the periodontal ligament: Figure 4 shows transverse sections of separated socket bones and mesial roots after mechanical testing. In the control specimens treated with PBS (Fig. $4 \mathrm{a}, \mathrm{b})$, the periodontal ligament was sheared between the bone and cementum surfaces, and the free surfaces of the ligament were rough and irregular. In contrast, in the specimens treated with 24 units $/ \mathrm{m} l$ of collagenase solution (Fig. $4 \mathrm{c}, \mathrm{d}$ ), most of the ligament remained on the bone side, and there was little adhered to the cementum surface. The ratios of ligament 


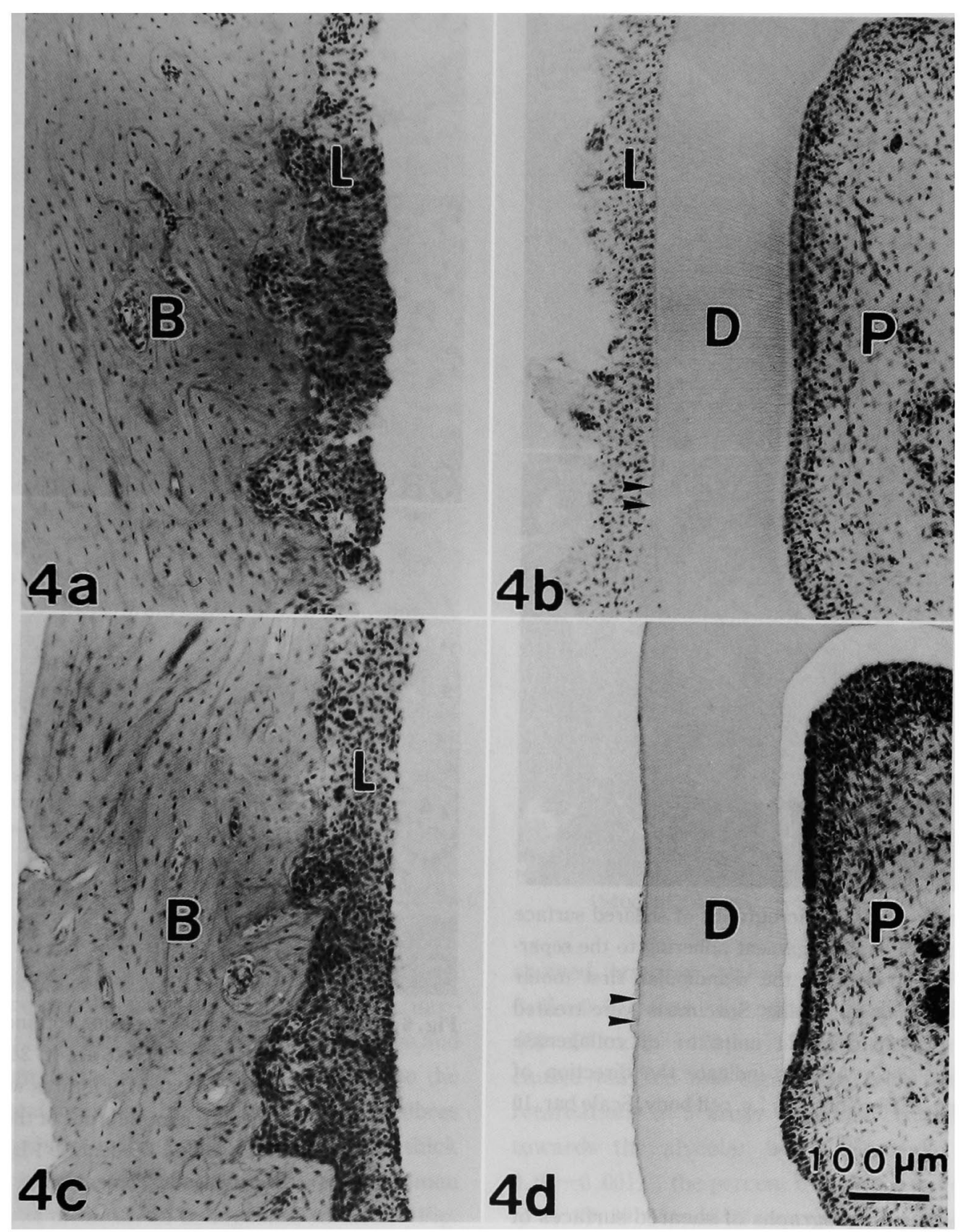

Fig. 4 Transverse sections of separated socket bones ( $4 \mathrm{a}$ and $4 \mathrm{c}$ ) and mesial roots ( $\mathrm{b}$ and $4 \mathrm{~d}$ ) of the mandibular first molar after mechanical testing. Sections were obtained from specimens treated with PBS ( $4 \mathrm{a}$ and $4 \mathrm{~b}$ ) or $24 \mathrm{units} / \mathrm{m} l$ of collagenase solution ( $4 \mathrm{c}$ and $4 \mathrm{~d}$ ). Pictures were taken on the buccal side of the mesial root. $\mathrm{B}$, bone ; D, dentine : L, periodontal ligament ; P, dental pulp ; arrowheads, cementum. Haematoxylin and eosin.

adhering to bone and to the cementum surface were $1.23 \pm 0.60(\mathrm{SD})$ in the control specimens $(n=3)$, and $6.49 \pm 1.66$ in the specimens treated with 24 units $/ \mathrm{m} l$ of collagenase solution $(n=3)$. The difference was significant (Student's $t$-test, $\mathrm{p}<0.01$ ).

2 ) Scanning electron microscopy : Figure 5 shows 


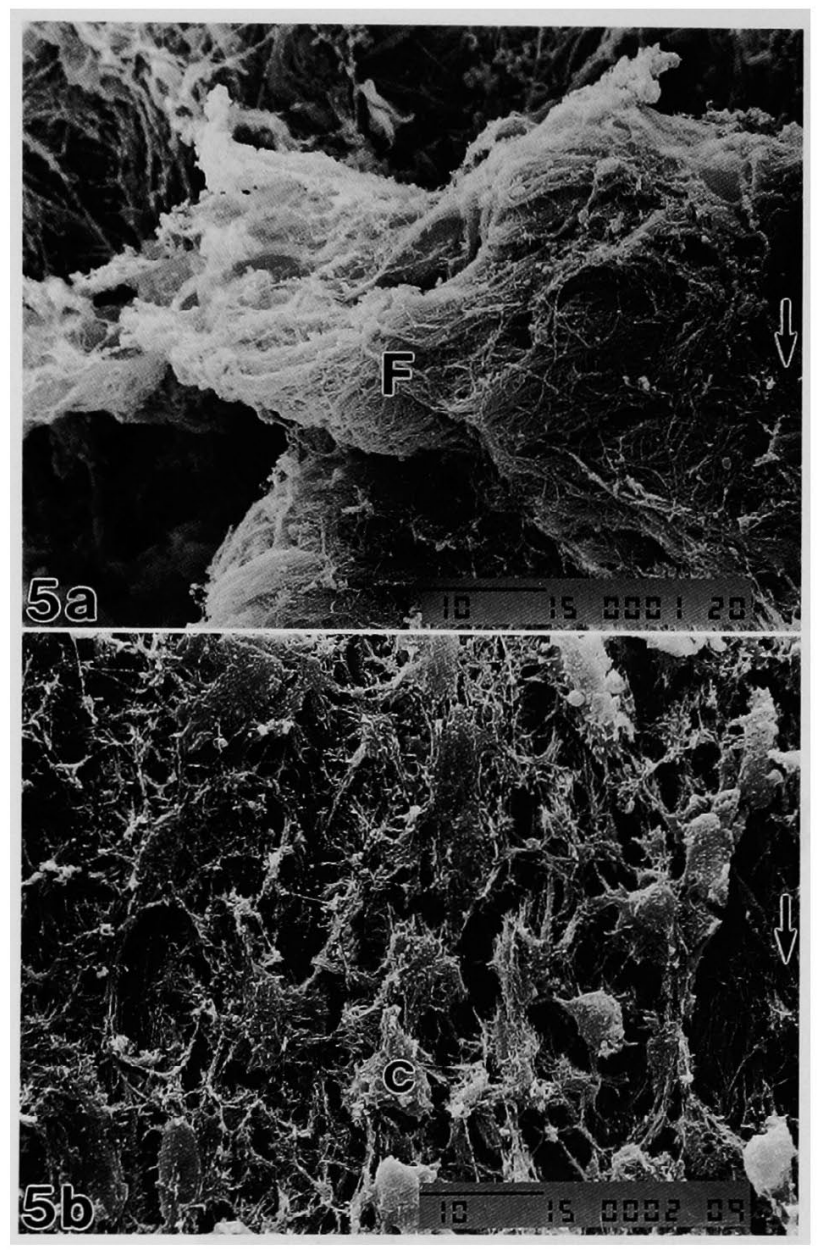

Fig. 5 Scanning electron micrographs of sheared surface of the periodontal ligament adhering to the separated mesial root of the mandibular first molar after mechanical testing. Specimens were treated with PBS (5 a) or 24 units $/ \mathrm{m} l$ of collagenase solution $(5 \mathrm{~b})$. Arrows indicate the direction of loading. F, fibre bundles ; c, cell body. Scale bar, 10 $\mu \mathrm{m}$.

scanning electron micrographs of sheared surfaces of the periodontal ligament adhering to the separated mesial roots after mechanical testing. In the control specimen treated with PBS (Fig. 5 a), the surface of the sheared ligament was irregular and rough, and thick bundles appeared as tightly packed collagen fibrils. In the specimen treated with 24 units $/ \mathrm{m} l$ of collagenase solution (Fig. $5 \mathrm{~b}$ ), periodontal cells were exposed, and only a small amount of thin fibrous material was observed around the cells.

3 ) Toluidine blue staining: Figure 6 shows

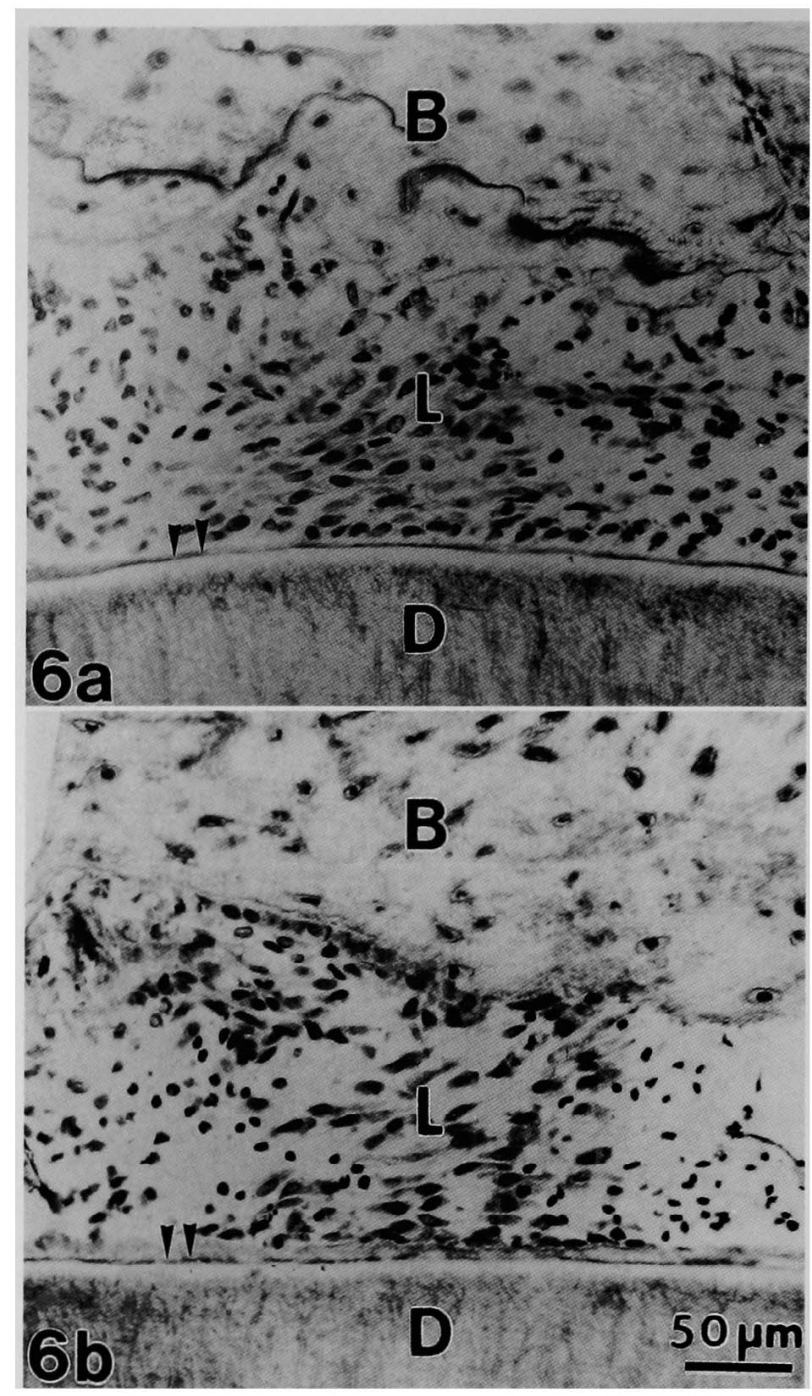

Fig. 6 Toluidine blue-stained sections obtained from specimens treated with PBS ( $6 \mathrm{a})$ or 24 units $/ \mathrm{m} l$ of collagenase solution ( $6 \mathrm{~b})$. Pictures were taken on the buccal side of the mesial root of the mandibular first molar. B, bone; $\mathrm{D}$, dentine ; L, periodontal ligament : arrowheads, cementum.

toluidine blue-stained sections of the buccal side of the mesial roots. In a control specimen treated with PBS (Fig. 6a), pyknotic periodontal cells were mostly observed near the cut surfaces of the specimens (left and right ends of the photo), with only a few in the central region of the ligament. In a specimen treated with 24 units $/ \mathrm{m} l$ of collagenase solution (Fig. 6 b), many pyknotic cells were observed near the cut surfaces, with some in the central region of the ligament.

4) Polarized light microscopy: In the control 


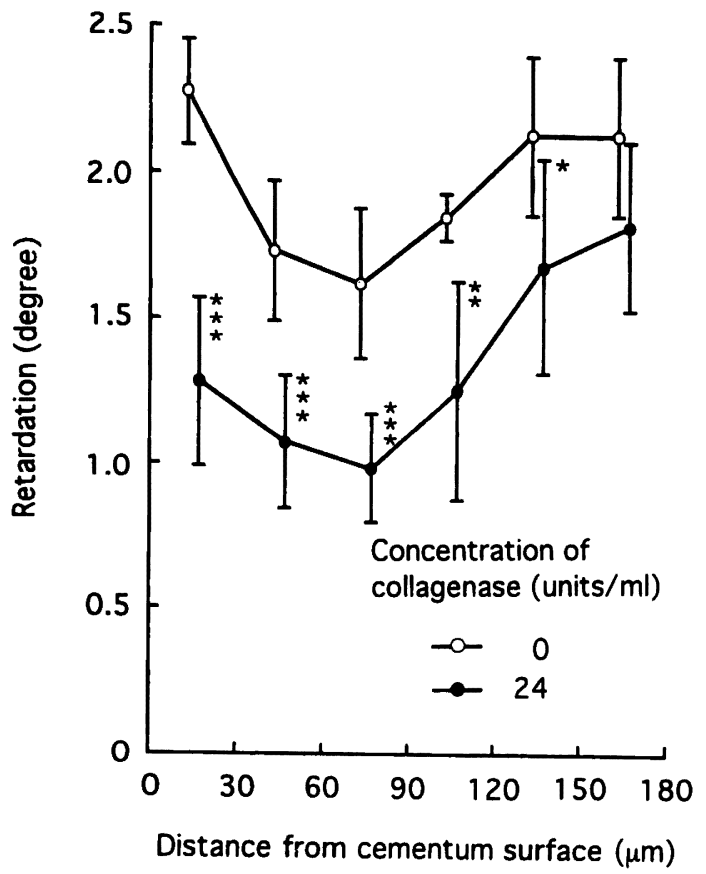

Fig. 7 Phase retardation of collagens across the periodontal ligament from the cementum surface towards the alveolar bones in 6 successive rectangular areas (see Fig. 1) after treatment with PBS or 24 units $/ \mathrm{m} l$ of collagenase solution. Each point and vertical bars represent the mean $\pm 1 \mathrm{SD}$ of 6 animals. Significant differences from respective control values (Student's $t$-test) : ${ }^{*} \mathrm{p}<0.05,{ }^{* *} \mathrm{p}<$ $0.01,{ }^{* * *} \mathrm{p}<0.001$.

specimen treated with PBS (Fig. 1 a), birefringent collagen fibre bundles were observed running obliquely across the ligament between the alveolar bones and the cementum surface. Fibre bundles adjacent to the cementum and bone surfaces, and Sharpey's fibres embedded in the alveolar bones appeared to be thick with more intense birefringence. In the specimen treated with 24 units $/ \mathrm{m} l$ of collagenase solution (Fig. $1 \mathrm{~b})$, birefringent collagen fibres appeared to be very thin with less intense birefringence. Figure 7 shows phase retardation of collagens across the periodontal ligament from the cementum surface towards the alveolar bones in 6 successive rectangular areas (Fig. $1 \mathrm{a}, \mathrm{b})$. Retardation values varied across the ligament in the control specimens treated with PBS (ANOVA, $\mathrm{p}<0.001)$. The areas neighbouring the cementum surface $(0-30 \mu \mathrm{m})$ and containing the alveolar bones with Sharpey's fibres $(120-150$ and $150-180 \mu \mathrm{m})$

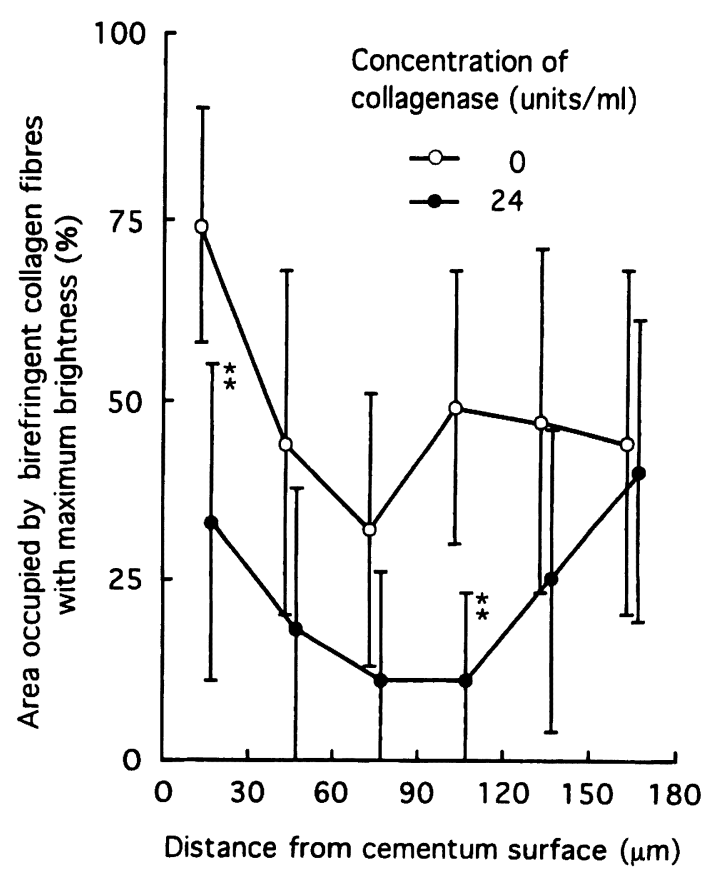

Fig. 8 Area occupied by birefringent collagen fibres with maximum brightness across the periodontal ligament from the cementum surface towards the alveolar bones in 6 successive rectangular areas after treatment with PBS or 24 units $/ \mathrm{m} l$ of collagenase solution. Each point and vertical bars represent the mean \pm 1 SD of 6 animals. ${ }^{* *}$ Significant differences from respective control values (Student's $t$-test), $\mathrm{p}<0.01$.

showed greater values (Scheffé's method, $\mathrm{p}<$ $0.05-0.01$ ) than the middle areas of the ligament $(30-60$ and $60-120 \mu \mathrm{m})$. Treatment with collagenase caused marked and significant reductions of phase retardations in 5 areas from the cementum surface towards the alveolar bones (Student's $t$-test, $\mathrm{p}<$ $0.05-0.001)$; the percent reductions were respectively $44,39,39,33$, and 22 on average in the 5 areas from the cementum surface. The 6 th area containing alveolar bones with Sharpey's fibres $(150-180 \mu \mathrm{m})$ showed only a $16 \%$ reduction of the retardation, which was not significant.

Figure 8 shows the area occupied by birefringent collagen fibres with maximum brightness across the periodontal ligament from the cementum surface towards the alveolar bones in 6 successive rectangular areas. Regional differences in the mean areas occupied by birefringent collagen fibres across the liga- 
ment were observed (Fig. 8) and were similar to those in the mean retardation values (Fig. 7). Treatment with collagenase also caused marked reductions of birefringent collagen fibres in the 5 areas from the cementum surface towards the alveolar bones; the percent reductions were respectively $55,59,66,78$, and 49 on average in the 5 areas from the cementum surface. Significant reductions (Student's $t$-test, $\mathrm{p}<$ $0.01)$ were only found in the 2 areas $(0-30$ and $90-120$ $\mu \mathrm{m})$. The 6 th area containing alveolar bones with Sharpey's fibres $(150-180 \mu \mathrm{m})$ did not show an appreciable reduction of birefringent collagen fibres after collagenase treatment.

\section{Discussion}

In the present study, we used bacterial collagenase from Clostridium histolyticum because of its specificity for collagen ${ }^{1,25,26)}$. Bacterial collagenase has been shown to consist of six different enzymes with different molecular weights ${ }^{25,26}$. The enzymes are capable of cleaving peptide bonds of collagen and have a specificity for the Pro-X-Gly-Pro-Y region, splitting between $\mathrm{X}$ and $\mathrm{Gly}^{27}$. Degradation of collagen by the enzymes has been documented in collagenous materials obtained from bovine tendon ${ }^{28)}$, rat $\operatorname{skin}^{29)}$, sheep skin ${ }^{30)}$, and bovine incisor $\operatorname{root}^{31,32)}$.

Following treatment with bacterial collagenase, pronounced reductions in the mechanical properties have been observed in various collagenous tissues $^{29,30,33)}$. Our biomechanical study also showed that bacterial collagenase caused dose-dependent decreases in overall stress levels of the stress-strain curves and in the mechanical parameters in the rat molar periodontal ligament. These results indicate the loss in stress-bearing ability of the periodontal ligament as the collagen is degraded by the enzymes.

Light microscopic analyses after mechanical testing revealed that the periodontal ligament ruptured in the middle region and/or near the bone surface in the control specimens, but mostly ruptured at the region adjacent to the cementum surface in the collagenasetreated specimens. In contrast, following removal of interfibrillar substances by treatment with $\alpha^{-}$ amylase, the periodontal ligament did not rupture at the region adjacent to the cementum surface but instead ruptured irregularly in the middle region of the ligament, as in the control specimens ${ }^{12)}$. This suggests that, unlike collagenase, $\alpha$-amylase did not weaken a specific region within the ligament. It is assumed that treatment with collagenase impaired the connection between the cementum and collagen fibres to a greater extent than the anchorage of Sharpey's fibres into the alveolar bones.

In the control specimens, we found regional differences of retardation values across the periodontal ligament. Collagen fibre bundles near the cementum and bone surfaces, and the Sharpey's fibres, had higher values than those in the middle region of the ligament. It has been shown that collagen fibres in the cementum- and bone-related regions of the periodontal ligament have higher intensities of birefringence than those in the middle region in the rat incisor $^{10,34,35)}$. It has been well established that the brightness or birefringence retardation is closely related to the number of collagen fibres, aggregational state, and arrangement of their macromolecular structures $^{22,36,37)}$. The higher values of retardation may reflect a parallel orientation and tightly packed condition of the periodontal collagen fibres near the cementum and bone surfaces, and Sharpey's fibres, as suggested by previous investigators ${ }^{4,38}$. We also found regional differences in areas occupied by birefringent collagen fibres across the periodontal ligament. The relative area occupied by collagen fibres was about 1.5 times greater in the region near the cementum surface than in the region near the alveolar bones. It is plausible that in the bone-related region of the ligament, blood vessels and nerve fibres may have occupied a large space but were not documented in the polarized light micrographs, thus reducing the relative area occupied by collagen fibres.

Following treatment with collagenase, the retardation values and the areas occupied by birefringent collagen fibres within the periodontal ligament were both reduced, particularly in the $0-120 \mu \mathrm{m}$ region from the cementum surface, indicating that the degree of collagen molecular organization and amount and density of collagen fibres were affected by the enzyme in this region. However, it may be that the relatively 
lower reductions in the areas containing the alveolar bones, $120-180 \mu \mathrm{m}$ from the cementum surface, were simply caused by poor penetration of collagenase into the mineralized alveolar bones and peripheral Sharpey's fibres during treatment. The specimens treated with 8 or 16 units $/ \mathrm{m} l$ collagenase showed dose-dependent reductions in the mean values of retar. dation and area occupied by birefringent collagen. For clarity, only the results obtained from the specimens treated with 24 units $/ \mathrm{m} l$ collagenase are shown in the present study.

Our combined biomechanical and polarized light microscopic observations provided a good assessment of the contribution of collagenous components to the tooth support system, and our findings support the notion that the periodontal collagen is a load-bearing, key structural component giving mechanical integrity to the ligament ${ }^{5,9,10,39)}$. In mouse and rat molars, collagen fibres in the periodontal ligament are reportedly thin and reduced in number during hypofunction ${ }^{40-42}$. The mechanical strength of the periodontal ligament of the hypofunctional teeth is also diminished in rat molars $^{43,44)}$ and incisors ${ }^{17,45,46)}$. These reports are consistent with a biomechanical contribution of collagenous components to the tooth support as shown in the present study.

It has been shown that removal of interfibrillar substances from the rat molar periodontal ligament by treatment with $\alpha$-amylase ${ }^{12)}$ or $\mathrm{EDTA}^{13)}$ also markedly reduces the mechanical strength of the ligament without affecting the histochemical or polarized microscopic features of the periodontal collagen fibres. Proteoglycans, the main constituents of interfibrillar substances, are known to localize in close association with periodontal collagen fibres or fibrils $^{13,47-52)}$. Interfibrillar components are also suggested to contribute significantly to the macromolecular orientation of collagen bundles ${ }^{53-55)}$. Thus, the interfibrillar substances, as well as the collagen fibres, are important in maintaining the structural and functional integrity of the ligament.

\section{Acknowledgements}

We wish to express our sincere gratitude to Profes- sor M. Chiba, Department of Pharmacology, and Professor T. Arai, Department of Periodontics \& Endodontics, Tsurumi University, for their continuous guidance and encouragement.

\section{References}

1) Melcher, A. H. and Eastoe, J.E. : The connective tissues of the periodontium. In: Biology of the periodontium. (edited by Melcher, A. H. and Bowen, W. H.), pp. 167-343, Academic Press, London, 1969.

2) Picton, D.C.A.: The effect of external forces on the periodontium. In : Biology of the periodontium. (edited by Melcher, A. H. and Bowen, W. H.), pp. 363-419, Academic Press, London, 1969.

3) Moxham, B. J. and Berkovitz, B. K. B. : The effects of external forces on the periodontal ligament. In : The periodontal ligament in health and disease. (edited by Berkovitz, B. K. B., Moxham, B. J. and Newman, H. N.), 2nd ed., pp. 215-241, MosbyWolfe, London, 1995.

4) Sloan, P. and Carter, D. H. : Structural organization of the fibres of the periodontal ligament. In: The periodontal ligament in health and disease. (edited by Berkovitz, B. K. B., Moxham, B. J. and Newman, H. N.), 2nd ed., pp. 35-53, Mosby-Wolfe, London, 1995.

5) Chiba, M. and Ohkawa, S. : Measurement of the tensile strength of the periodontium in the rat mandibular first molar. Arch. Oral Biol. 25: 569-572, 1980.

6) Ohshima, S. : Effects of lathyrogens on the mechanical properties of the periodontium in the rat mandibular incisor. Tsurumi Univ. Dent. J. $8: 345-356$, 1982.

7) Kondo, I. : Analysis of stress-strain curves in the rat molar periodontal ligament following administra. tion of $\beta$-aminopropionitrile (BAPN). Folia Pharmacol. Jpn. 97 : 297-306, 1991.

8) Yamaguchi, S. : Analysis of stress-strain curves at fast and slow velocities of loading in vitro in the transverse section of the rat incisor periodontal ligament following the administration of $\beta$-aminopropionitrile. Arch. Oral Biol. 37 : 439-444, 1992.

9) Moxham, B. J. and Berkovitz, B. K. B. : The mobility of the lathyritic rabbit mandibular incisor in response to axially-directed extrusive loads. Arch. Oral Biol. 29 : 773-778, 1984.

10) Komatsu, K. and Viidik, A. : Changes in the fibre 
arrangement of the rat incisor periodontal ligament in relation to various loading levels in vitro. Arch. Oral Biol. 41 : 147-159, 1996.

11) Hoffman, A. S. and Daly, C. H. : A commentary on the use of enzyme probes to elucidate the contributions of individual components to soft-tissue biomechanics in vitro. In : Biology of collagen. (edited by Viidik, A. and Vuust, J.), pp. 297-312, Academic Press, London, 1980.

12) Watanabe, Y. and Komatsu, K. : Biomechanical and morphological studies on the periodontal ligament of the rat molar after treatment with $\alpha^{-}$ amylase in vitro. Connect. Tissue Res. $36: 35-49$, 1997.

13) Kanazashi, M. and Komatsu, K. : In vitro effects of ethylenediaminetetraacetic acid and $\mathrm{pH}$ on biomechanical properties and morphologic features of the rat molar periodontal ligament. J. Oromax. Biomech. 4 : 1-16, 1999.

14) Komatsu, K. and Chiba, M. : The effect of velocity of loading on the biomechanical responses of the periodontal ligament in transverse sections of the rat molar in vitro. Arch. Oral Biol. 38:369-375, 1993.

15) Chiba, M. and Komatsu, K. : Mechanical responses of the periodontal ligament in the transverse section of the rat mandibular incisor at various velocities of loading in vitro. J. Biomech. $26: 561-570,1993$.

16) Mandel, U., Dalgaard, P. and Viidik, A. : A biomechanical study of the human periodontal ligament. J. Biomech. 19 : 637-645, 1986.

17) Komatsu, K. : In vitro mechanics of the periodontal ligament in impeded and unimpeded rat mandibular incisors. Arch. Oral Biol. 33: 783-791, 1988.

18) Chiba, M., Yamane, A., Ohshima, S. and Komatsu, $\mathrm{K}$. : In vitro measurement of regional differences in the mechanical properties of the periodontal ligament in the rat mandibular incisor. Arch. Oral Biol. $35: 153-161,1990$.

19) Viidik, A. : Mechanical properties of parallel-fibred collagenous tissues. In : Biology of collagen. (edited by Viidik, A. and Vuust, J.), pp. 237-255, Academic Press, London, 1980.

20) Haut, R.C. : The influence of specimen length on the tensile failure properties of tendon collagen. J. Biomech. 19 : 951-955, 1986.

21) Bennett, H. S. : The microscopical investigation of biological materials with polarized light. In: McClung's Handbook of Microscopical Technique. (edited by McClung-Jones, R.), 3rd ed., pp. 591-677, Hafner, New York, 1961.

22) Whittaker, P., Boughner, D. R. and Kloner, R. A. : Analysis of healing after myocardial infarction using polarized light microscopy. Am. J. Pathol. $134: 879-893,1989$.

23) Nollie, G. J., Sandhu, H. S., Cernovsky, Z.Z. and Canham, P. B. : Regional differences in molecular cross-linking of periodontal ligament collagen of rat incisor, by polarizing microscopy. Connect. Tissue Res. 33 : 283-289, 1996.

24) Sokal, R. R. and Rohlf, F. J. : Single classification analysis of variance. In: Biometry. (edited by Sokal, R. R. and Rohlf, F. J.), 2nd ed., pp. 208-270, W. H. Freeman and company, New York, 1981.

25) Bond, M. D. and van Wart, H. E. : Purification and separation of individual collagenases of Clostridium histolyticum using red dye ligand chromatography. Biochemistry $23: 3077-3085,1984$.

26) Bond, M. D. and van Wart, H. E. : Characterization of the individual collagenases from Clostridium histolyticum. Biochemistry 23 : 3085-3091, 1984.

27) Harper, E., Berger, A. and Katchalski, E. : The hydrolysis of poly (L-prolyl-glycyl-L-prolyl) by bacterial collagenase. Biopolymers $11: 1607-1612$, 1972.

28) Huang, C. and Yannas, I. V. : Mechanochemical studies of enzymatic degradation of insoluble collagen fibers. J. Biomed. Mater. Res. Symposium 8 : 137-154, 1977.

29) Oxlund, H. and Andreassen, T. T.: The roles of hyaluronic acid, collagen and elastin in the mechanical properties of connective tissues. J. Anat. 131 : 611-620, 1980.

30) Olde Damink, L. H. H., Dijkstra, P. J., van Luyn, M. J. A., van Wachem, P. B., Nieuwenhuis, P. and Feijen, J. : Changes in the mechanical properties of dermal sheep collagen during in vitro degradation. J. Biomed. Mater. Res. 29 : 139-147, 1995.

31) Klont, B., Damen, J. J. M. and ten Cate, J. M. : Degradation of bovine incisor root collagen in an in vitro caries model. Arch. Oral Biol. $36: 299-304$, 1991.

32) Klont, B. and ten Cate, J. M. : Susceptibility of the collagenous matrix from bovine incisor roots to proteolysis after in vitro lesion formation. Caries Res. 25 : 46-50, 1991.

33) Hoffman, A. S., Park, J. B. and Abrahamson, J. : Sequential enzymolysis of ligament and resultant 
stress-strain behavior. Biomater. Med. Dev. Art. Org. $1: 453-467,1973$.

34) Hindle, M. O.: The intermediate plexus of the periodontal membrane. In: The mechanisms of tooth support. A symposium. (edited by Anderson, D. J., Eastoe, J. E., Melcher, A. H. and Picton, D. C. A.), pp. 66-71, John Wright \& Sons, Bristol, 1967.

35) Komatsu, K., Yamazaki, Y., Yamaguchi, S. and Chiba, M.: Comparison of biomechanical properties of the incisor periodontal ligament among different species. Anat. Rec. 250 : 408-417, 1998.

36) Doillon, C. J., Dunn, M. G., Bender, E. and Silver, F. H. : Collagen fiber formation in repair tissue: development of strength and toughness. Collagen Res. Rel. 5 : 481-492, 1985.

37) Vidal, B. C. : Evaluation of the carbohydrate role in the molecular order of collagen bundles: microphotometric measurements of textural birefringence. Cell. Molec. Biol. 32 : 527-535, 1986.

38) Gathercole, L. J. and Keller, A. : Crimp morphology in the fibre-forming collagens. Matrix 11:214-234, 1991.

39) Picton, D. C. A. : The effect on vertical tooth mobility of extraction and immediate replacement of incisors (Macaca fascicularis). Arch. Oral Biol. 36 : 85-87, 1991.

40) Amemiya, A. and Abe, S. : An electron microscopic study on the effects of extraction of opposed teeth on the periodontal ligament in rats. Jpn. J. Oral Biol. 22: 72-83, 1980.

41) Beertsen, W. : Collagen phagocytosis by fibroblasts in the periodontal ligament of the mouse molar during the initial phase of hypofunction. J. Dent. Res. 66 : 1708-1712, 1987.

42) Short, E. and Johnson, R. B. : Effects of tooth function on adjacent alveolar bone and Sharpey's fibers of the rat periodontium. Anat. Rec. 227:391-396, 1990.

43) Kinoshita, Y., Tonooka, K. and Chiba, M.: The effect of hypofunction on the mechanical properties of the periodontium in the rat mandibular first molar. Arch. Oral Biol. 27 : 881-885, 1982.

44) Ohshima, S., Komatsu, K., Yamane, A. and Chiba, M.: Prolonged effects of hypofunction on the mechanical strength of the periodontal ligament in rat mandibular molars. Arch. Oral Biol. 36: 905-911, 1991.
45) Chiba, M., Ohshima, S., Kuroda, T. and Ohkawa, S. : Effects of repeated shortenings and of artificial restraint on the tensile strength of the periodontium of the rat mandibular incisor. Arch. Oral Biol. 26 : 135-141, 1981.

46) Komatsu, K. and Chiba, M. : Analysis of stressstrain curves and histological observations on the periodontal ligament of impeded and unimpeded rat incisors at low velocities of loading. Jpn. J. Oral Biol. 38 : 192-202, 1996.

47) Häkkinen, L., Oksala, O., Salo, T., Rahemtulla, F. and Larjava, H. : Immunohistochemical localization of proteoglycans in human periodontium. J. Histochem. Cytochem. 41 : 1689-1699, 1993.

48) Erlinger, R., Willershausen-Zönnchen, B. and Welsch, U. : Ultrastructural localization of glycosaminoglycans in human gingival connective tissue using Cupromeronic blue. J. Periodont. Res. 30 : 108-115, 1995.

49) Kagayama, M., Sasano, Y., Mizoguchi, I., Kamo, N., Takahashi, I. and Mitani, H. : Localization of glycosaminoglycans in periodontal ligament during physiological and experimental tooth movement. J. Periodont. Res. 31:229-234, 1996.

50) Ababneh, K. T., Hall, R. C. and Embery, G. : Immunolocalization of glycosaminoglycans in ageing, healthy and periodontally diseased human cementum. Arch. Oral Biol. 43:235-246, 1998.

51) Ababneh, K. T., Hall, R. C. and Embery, G. : The proteoglycans of human cementum : immunohistochemical localization in healthy, periodontally involved and ageing teeth. J. Periodont. Res. 34 : 87-96, 1999.

52) Fujii, T. and Hirabayashi, Y. : Histochemical studies of glycosaminoglycans in developing periodontal ligaments of ICR mice. Anat. Rec. 254 : 465-473, 1999.

53) Vidal, B. C. : The part played by proteoglycans and structural glycoproteins in the macromolecular orientation of collagen bundles. Cell. Molec. Biol. 26 : 415-421, 1980.

54) Bartold, P. M.: Proteoglycans of the periodontium: Structure, role and function. J. Periodont. Res. 22: 431-444, 1987.

55) Scott, J. E. : Extracellular matrix, supramolecular organisation and shape. J. Anat. 187:259-269, 1995. 